\title{
DIAGNÓSTICO FÍSICO-CONSERVACIONISTA - DFC: INSTRUMENTO PARA O PLANO DE BACIAS HIDROGRÁFICAS - UMA APLICAÇÃO NA BACIA DO RIO TAGAÇABA - MUNICÍPIO DE GUARAQUEÇABA - PR
}

\author{
Eliane Regina Ferretti*
}

\author{
TESE DE DOUTORADO - Programa de Pós-Graduação em Geologia - UFPR \\ DATA DE DEFESA: 04 jul. 2003
}

Tendo em vista o aumento de áreas degradadas, torna-se necessário desenvolver metodologias capazes de avaliar a degradação dos recursos naturais. Assim, uma metodologia para o diagnóstico da situação real dos recursos naturais numa bacia hidrográfica (reconhecida como a melhor unidade para o manejo) passa a ser um instrumento necessário para a preservação e gerenciamento destes recursos. O diagnóstico físico-conservacionista objetiva determinar o potencial de degradação ambiental. A metodologia parte da definição de sete parâmetros: grau de semelhança entre a cobertura vegetal original e a atual; grau de proteção fornecido ao solo pela cobertura vegetal atual; declividade média; erosividade da chuva; potencial erosivo dos solos; densidade de drenagem e o balanço hídrico. Estes parâmetros são expressos em uma fórmula descritiva, estabelecendo 0 risco de degradação, o que possibilita a análise qualitativa do estado ambiental da bacia, que é retratada na Carta de Conflitos do Uso do Solo. Na Carta do Uso Racional do Solo - Sugestão identifica-se áreas sobre-utilizadas (usos além da sua capacidade, com alta degradação do solo), áreas subutilizadas (usos abaixo de sua capacidade produtiva) e áreas com uso correspondente. O estado ambiental da bacia, identificado após aplicação do DFC, constitui um subsídio básico para programas de extensão rural e/ou projetos que visem à recuperação ambiental da área, pois fornece indicativos para a racionalização do uso e manejo dos recursos. O DFC foi utilizado em alguns estudos no Brasil, fundamentando a pesquisa realizada por Beltrame (1990), Ferretti (1998), o projeto de Proteção Ambiental da Bacia Hidrográfica do Rio Tibagi - COPATI no Paraná, estudos na bacia do rio Itajaí, em Santa Catarina etc. Mas, faltam estudos comparativos para verificação da real viabilidade de utilização dessa metodologia. A aplicação do DFC em um ambiente frágil por sua natureza, como os ecossistemas costeiros, e potencialmente estressado diante das pressões impostas pelas formas de ocupação, vem de encontro com a necessidade de se avaliar a sua aplicabilidade e eficácia. Aplicar o DFC na bacia do rio Tagaçaba, Município de Guaraqueçaba (litoral do Paraná), possibilitou uma análise mais aprimorada da adequação dos parâmetros que compõem o DFC, como reais indicadores do estado de degradação de uma bacia hidrográfica, objetivo principal do presente trabalho. Em um segundo momento, os resultados da aplicação do DFC na bacia do Rio Tagaçaba foram comparados com os resultados do DFC da bacia do Rio Marrecas, uma vez que essas duas bacias possuem ambientes com características físicas e socioeconômicas completamente diferentes e, também, com a metodologia utilizada pelo Ipardes para o zoneamento da APA de Guaraqueçaba, Zoneamento Ecológico Econômico. As comparações possibilitaram uma avaliação mais detaIhada do DFC, visando demonstrar que o DFC atende a demanda do planejamento ambiental em melhores condições que o ZEE. O DFC define parâmetros flexíveis em relação à atribuição de valores, mas, que se tornam objetivos e operacionais em qualquer situação ambiental. Como os parâmetros e índices são flexíveis em sua concepção, permite, se for o caso, a participação de outras vertentes de decisão, como a institucional e a comunitária. Em relação ao objetivo dessa tese, analisar a adequação dos parâmetros que compõem o DFC como reais indicadores do estado de degradação de uma bacia hidrográfica, ressalta-se a eficiência dessa metodologia, cujos resultados qualitativos são transformados em quantitativos, espacializando as áreas mais críticas, atendendo a demanda do planejamento ambiental. 